\title{
EVENTS
}

\section{REPORT ON THE IMPLEMENTATION OF THE SCIENTIFIC AND EDUCATIONAL PROJECT VII ALL-RUSSIAN CONFERENCE OF STUDENTS AND YOUNG SCIENTISTS WITH INTERNATIONAL PARTICIPATION «PSYCHOLOGY AND MEDICINE: THE WAY OF FINDING THE OPTIMAL INTERACTION»}

\section{November 25-26, 2020}

The all-Russian conference of students and young scientists with international participation "Psychology and medicine: ways to find optimal interaction" is held at the University for the seventh time and is the title event for the clinical psychology faculty of the Ryazan State Medical University. The conference was held for the first time in an electronic environment on the ZOOM platform. Information support for the conference is available on the page in the Vkontakte group.

The traditional theme of the conference is the mutual exchange of ideas, achievements in science and practice in the field of clinical psychology, which combines psychological and medical $\longrightarrow$ discourses. Successful communication of specialists and scientific and practical interaction can ensure high quality of clinical and psychological care.

This year, the Organizing Committee invited delegates to discuss the prospects for the development of clinical psychology in modern conditions, the points of contact between psychology and medicine, and the technology of joint work of a clinical psychologist and a doctor.

The aims of the conference were stated:

$\checkmark$ mutual exchange of experience in organizing the educational process and research work at the faculties of clinical psychology;

discussion of the results of research activities of students and young scientists in various areas of clinical psychology; 
The planned results of the conference were as follows:

- increasing academic mobility of students and young scientists and strengthening scientific and practical ties between universities;

- professional self-expression of clinical psychologists;

- defining topics and selecting areas of inter-university scientific interaction.

More than 300 students, young scientists and lecturers from Russian universities took part in the conference: Ryazan, Moscow, Kursk, Tula, Yaroslavl, Krasnoyarsk, Yekaterinburg, St. Petersburg, Smolensk, Voronezh, Chelyabinsk, Blagoveshchensk, Kirov, and other cities, as well as from Kazakhstan, Uzbekistan, and Belarus. There are 128 active participants of the conference who gave presentations, master classes, or participated in the Olympiad.

During the conference, 4 discussion platforms were held, which included 36 reports, 7 master classes, and 2 open lectures.

During the conference, the final of the all-Russian Olympiad in clinical psychology for psychology students was held, which was attended by more than 150 students, and 79 people reached the final. The final included final testing and the final of the individual championship. 64 students from 52 universities of Russia and the CIS participated in the final testing, 9 people reached the final of the personal championship.

The conference was attended by open lectures by the Dean of the faculty of clinical psychology of Dubna University, professor, doctor of psychology V.B. Khoziev and head of the department of clinical psychology of the RyazSMU, candidate of psychological sciences A.G. Faustova.

As a part of the conference, a competition of scientific publications was held, which was attended by 36 students and young scientists from different universities in Russia. 4 winners will be published in online edition of " Personality in a changing world: health, adaptation, development", included in the list of VAK of the Ministry of education.

The importance of the event for the development of professional education and improvement of clinical psychologists can hardly be overestimated. Students and young scientists from leading faculties of clinical psychology in Russia had the opportunity not only to exchange opinions, but also to learn from colleagues' experience to activate scientific research, establish and strengthen professional ties.

The conference became an effective virtual scientific and educational environment for future specialists in the field of clinical psychology. We are confident that the conference will give a new impetus to the development of general cultural, general professional and professional competencies of future clinical psychologists.

Ryazan State Medical University considers the experience of holding the all-Russian scientific and practical conference of students and young scientists to be an effective scientific and educational project and plans to develop it in the future. 
NETWORK SCIENTIFIC JOURNAL «PERSONALITY IN A CHANGING WORLD: HEALTH, ADAPTATION, DEVELOPMENT» www.humjournal.rzgmu.ru / E-mail: humjournal@rzgmu.ru

.ДАТА ПОСТУПЛЕНИЯ: 27.11.2020. ДАТА ПРИНЯТИЯ В ПЕЧАТЬ: 01.12.2020.

\section{ССЫДКА ДАЯ ЦИТИРОВАНИЯ:}

Отчет о реализации научно-образовательного проекта VII Всероссийская конференция студентов и молодых учёных с международным участием «Психодогия и медицина: пути поиска оптимального взаимодействия» // Дичность в меняющемся мире: здоровье, адаптация, развитие. 2020. Т. 8, №4(31). С. 470-472. Доступно по: http://humjournal.rzgmu.ru/ art\&id=463. Ссылка активна на чч.мм.гггг. doi:10.23888/ humJ20204470-472
PAPER RECEIVED: 27.11.2020.

PAPER ACCEPTED: 01.12.2020.

\section{REFERENCE FOR CITING:}

Report on the implementation of the scientific and educational project The VII All-Russian Conference of Students and Young Scientists with International Participation «Psychology and Medicine: Ways to Find an Optimal Interaction». Personality in a changing world: health, adaptation, development. 2020;8(4):470-2. Available at: http://hum journal.rzgmu.ru/art\&id=463. Accessed: dd Month yyyy. doi:10.23888/humJ20204470-472 